\title{
Efficient Precipitation Methods of Inulinase from Endophytic Bacteria Bacillus aquimaris Isolated from Jerusalem Artichoke
}

\author{
Kanokwan Chansoda \\ Department of Microbiology, \\ Faculty of Science, Khon Kaen University, \\ Khon Kaen, Thailand
}

\author{
Sophon Boonlue \\ Department of Microbiology, \\ Faculty of Science, Khon Kaen University, \\ Khon Kaen, Thailand
}

\author{
Wiyada Mongkolthanaruk* \\ Department of Microbiology, \\ Faculty of Science, Khon Kaen University, \\ Khon Kaen, Thailand
}

\begin{abstract}
Inulinase is an enzyme that hydrolyzes inulin to oligosaccharides used in the food industry. Inulin is a source of fructose production using inulinase hydrolysis in one step. Jerusalem artichoke (Helianthus tuberosus L.) is a high inulin plant that was accumulating inulin in tubers. Thus, the endophytic bacterium, Bacillus aquimaris was isolated from Jerusalem artichoke to determined inulinase activity. This bacterium produced high inulinase when grown in Luria Bertani medium containing $1 \%$ inulin as the carbon and energy source with incubation temperature at $37^{\circ} \mathrm{C}$ for 20 hours and shaking speed of $150 \mathrm{rpm}$. The crude enzyme showed specific inulinase activities at $1.61 \mathrm{U} / \mathrm{mg}$ protein after incubation at $55^{\circ} \mathrm{C}$ for $20 \mathrm{~min}$ in the presence of the inulin substrate. The suitable method of enzyme concentration was studied in this work for purification and characterization in further. There were four methods for protein precipitation using ammonium sulfate, ethanol, butanol, and 2-steps of salt and alcohol. The best-precipitated protein method was $50 \%$ of ethanol, giving $53 \%$ protein recovery with specific activity at $26.21 \mathrm{U} / \mathrm{mg}$. This method was efficient with inulinase not only protein concentration but also protein purification (16.24 fold).
\end{abstract}

Keywords: Inulin, inulinase, endophytic bacteria

Received: 17 July 2018; Accepted: 18 September 2018; Published: 14 November 2018

\section{INTRODUCTION}

Inulin is a polysaccharide (fructan type) of linear chain $\beta$ - $(2,1)$ linked fructan residues attached to a terminal sucrose molecule [1]. Inulin accumulates in several plants such as leak, onion, garlic, tulip, chicory and Jerusalem artichoke. The beneficial effects of inulin and oligofructose have been reported in a large number of health promoting functions; thus, there are wide applications in various types of foods like confectionery, fruit preparations, milk desserts, yogurt and fresh cheese, baked goods, chocolate, ice cream and sauces. Inulin can also be used for the preparation of fructose syrups [2] by hydrolysis of enzymes known as inulinases. Inulinase ( $\beta$-fructosidase, EC 3.2.1.7) catalyze the $\beta$-(2,1) link of inulin. The characteristic of inulinase has two forms; (i) exo-inulinase degrade $\beta$ - $(2,1)$ linked bond of non-reducing area, producing fructose [3]; (ii) endoinulinase degrade a random area of substrate, giving inulooligosaccharide, which is low in sweetener, prebiotic and used as component of a healthy diet $[4,5]$.

Fructose is a basic monosaccharide sugar that is high sweetness. It can use as a sweetener which is a good

\footnotetext{
${ }^{*}$ Correspondence concerning this article should be addressed to Wiyada Mongkolthanaruk, Department of Microbiology, Faculty of Science, Khon Kaen University, Khon Kaen, Thailand. E-mail: wiymon@kku.ac.th

(c) 2018 The Author(s). Published by KKG Publications. This is an Open Access article distributed under a Creative Commons AttributionNonCommercial-NoDerivatives 4.0 International License.
} 
choice for those affected by obesity and diabetes mellitus. Moreover, it is widely used in many foods, beverages and the pharmaceutical industry [6]. Fructose can be used as a raw material in fermentation industries such as the production of ethanol, acetone and butanol [7]. These industries normally use chemical reactions to change sucrose into fructose including fructose syrup. Mostly, sucrose is produced from starch using many steps of enzymes, such as -amylase, amyloglucosidase and glucose isomerase. To use a single-step enzymatic reaction for fructose production, inulinase is a proper enzyme to give yields up to $95 \%$ from inulin substrate [2].

Endophytic bacteria that live inside high inulin plant as Jerusalem artichoke should have inulinase activity specific to inulin. Also, Jerusalem artichoke demonstrates good growth in poor soil, high tolerance to various plant diseases and very high carbohydrate yields [8]. This plant is $11-20 \%$ by weight of carbohydrates, $70-90 \%$ of these being inulin [9]. Therefore, the endophytic bacterium, Bacillus aquimaris isolated from Jerusalem artichoke, which showed high inulinase activity in medium containing inulin was used in this study for the determination of a suitable procedure of protein precipitation. This method will be considered for the purification and characterization of the enzyme.

\section{LITERATURE REVIEW}

Glycoside Hydrolases (GH) play important roles in various biological processes in plant, fungi, and bacteria as well as the biosynthesis of glycans including plant defenses, cell wall metabolism, signaling, and the mobilization of storage reserves. The GH enzymes show a common structure of $\beta$-propeller catalytic domain with three conserved amino acids including aspartate (D) in 'WMNDPNG' motif, aspartate (D) in RDP motif and glutamate (E) in 'EC' motif. This active site located in the deep axial pocket of the catalytic domain. The propeller structure has 5 of fold blades that each blade exhibits four antiparallel $\beta$-strands with the classical ' $\mathrm{W}$ ' topological structure around the center of the axis in Nterminal domain. It enclosed a negatively charged cavity of the active site. All of inulinase enzymes contain the consensus-conserved motifs R-D-P-K-V-F-W-H and W-M-N-D-P-N-G. The consensus motif (WMNDPNGL) acts as a nucleophile, and another consensus-conserved motif (RDPKVF) has a key role in catalytic activity [10]. Other conserved motif 'SVEVF', 'RDP', 'EC (V) P', 'Q' and 'FS (T)' involved in catalytic of exo-inulinase, except on motif 'SVEVF' which did not found in exo-inulinase producing yeast; therefore, yeast do not produced any endo-inulinase [11]. In exo-inulinase and endo-inulinase are conserved in motif 'SVEVE' that involved to attack inulin and levan substrates [12].

There are many methods for protein precipitation; the most popular one is ammonium sulfate precipitation as it has much a higher solubility than any of the phosphate salts. The protein solubility usually decreases at higher salt concentrations, leading to protein concentration; this effect is called salting-out. Organic solvents can also precipitate proteins, such as ethanol and butanol. The organic solvents decrease the solubility of proteins at low temperatures; however, alcohols and other organic solvents are protein destabilizers and can denature proteins at high concentrations or high temperatures due to their favorable interactions with hydrophobic groups [13]. For tertiary butanol, it is normally formed miscible with water, but upon the addition of enough salt. Therefore, t-butanol is used with ammonium sulfate by separating protein in interphase between the lower aqueous and upper t-butanol phase, termed three-phase partitioning [14, 15].

There had many reports for inulinase precipitation from bacteria. [16] used $60 \%$ of ethanol to precipitated inulinase of Arthrobacter aurescens SK8.001 with a 1.75-fold increase in the specific activity. The chilled ethanol at $85 \%$ showed the ability of inulinase precipitation with $80 \%$ recovery in Kluyveromyces marxianus YS-1 [4]. For salting out method, the ammonium sulfate concentration was a different application in range of 20-100\%, e.g. inulinase of Bacillus cereus MU-31 was precipitated at $80 \%$ [17], inulinase of Pseudomonas putida was 40-80\% [18] and inulinase of Xanthomonas campestris pv. phaseoli KM24 was 20-100\% [19]. The 3 phase protein portioning of inulinase was reported in $\mathrm{As}$ pergillus niger using $30 \%$ of ammonium sulfate with 1.0 $: 0.5 \mathrm{v} / \mathrm{v}$ ratio of t-butanol, giving $88 \%$ recovery and 10.2 fold of purification [20]. It is likely that the inulinase enzyme can precipitate in both salts and alcohol depending on suitable condition in each method.

\section{MATERIALS AND METHOD}

\section{A. Bacterial Cultivation}

The endophytic bacteria, Bacillus aquimaris 3.13 isolated from Jerusalem artichoke was transferred to LB broth containing $1 \%$ inulin, grown at $37^{\circ} \mathrm{C}$ for $20 \mathrm{~h}$ with shaking $(150 \mathrm{rpm})$. The cell was precipitated at 10,000 rpm of centrifugation for $10 \mathrm{~min}$. The supernatant was collected for the crude enzyme.

\section{B. Determination of Inulinase Activity}

The crude enzyme $(0.5 \mathrm{ml})$ was added into $1.5 \mathrm{ml}$ of $50 \mathrm{mM}$ sodium phosphate buffer ( $\mathrm{pH}$ 6.0) containing $1 \%$ inulin. The mixture was incubated at $55^{\circ} \mathrm{C}$ for $20 \mathrm{~min}$; 
the reaction was stopped on ice for $5 \mathrm{~min}$. Inulinase activity was assayed by the determination of reducing sugars using DNS method [21]. Definition of inulinase (1U) is defined as one micromole of reducing sugar produced by the amount of enzyme in a minute under the assay condition. Protein contents were measured by Lowry's method [22], using bovine serum albumin as a standard.

\section{Test of a Suitable Method for Inulinase Concentra- tion}

1) Ammonium sulfate precipitation: The $10 \mathrm{ml}$ of crude enzyme was mixed with ammonium sulfate at 20, 40, 60 or $80 \%$ and then continuously stirred during incubation at $4^{\circ} \mathrm{C}$ for $1 \mathrm{~h}$. The pellets were collected by centrifugation at $8,000 \mathrm{rpm}$ for $15 \mathrm{~min}$. The pellets were dissolved in a small amount of sodium phosphate buffer $(50 \mathrm{mM}, \mathrm{pH}$ 6.0 ). The protein contents and inulinase activity were determined to find an optimum concentration of salts.

2) Alcohol precipitation: The crude enzyme $(10 \mathrm{ml})$ was mixed with ethanol or butanol in the ratio of 20, 30, 40 or $50 \%$, was stirred at $4{ }^{\circ} \mathrm{C}$ for $1 \mathrm{~h}$. The pellets were kept at $8,000 \mathrm{rpm}$ for $15 \mathrm{~min}$ by centrifugation and then dissolved with sodium phosphate buffer ( $50 \mathrm{mM}, \mathrm{pH} 6.0$ ). The protein and enzyme activity was determined to find a suitable and optimum concentration of alcohol.

3) 2-Steps of salt and alcohol: This method was adapted from the three-phase partitioning (TPP) [6]. The $10 \mathrm{ml}$ of crude enzyme were mixed with ammonium sulfate $(30 \%$ $\mathrm{w} / \mathrm{v}$ ), after that 1:0.5 ratio of t-butanol was added. The mixture was incubated at $25^{\circ} \mathrm{C}$ for $1 \mathrm{~h}$; the centrifugation at 2,000 rpm was performed for $15 \mathrm{~min}$. The protein was dissolved with sodium phosphate buffer (50 mM, pH 6.0). The protein and enzyme activity was determined.

\section{RESULTS AND DISCUSSION}

There were four methods for precipitation of inulinase from $B$. aquimaris: ammonium sulfate, ethanol, t-butanol, and 2-steps of salt and alcohol. The precipitation of inulinase enzyme by ammonium sulfate was varied from 20-80\% saturation (Figure 1(a)). The highest protein precipitation was achieved at $20 \%$ ammonium sulfate saturation, giving total enzyme activity at $138 \mathrm{U}$ and high amounts of protein. It was similar to some enzymes that precipitated at low concentration of salt; for example, the $30-40 \%$ of ammonium sulfate was used to precipitate xylanases produced from Thermomyces lanuginosus and its mutant by overnight saturation at $0^{\circ} \mathrm{C}$ [23]. Gymnoascella citrina produced novel endoglucanase under solid-state conditions; the precipitation of crude enzyme was suitable at $35 \%$ of ammonium sulfate under condition at $0^{\circ} \mathrm{C}$ and continually overnight at $4^{\circ} \mathrm{C}$ [24]. The inulinase of $X$. campestris pv. phaseoli KM24 was precipitated at $20-100 \%$ of ammonium sulfate for $16 \mathrm{~h} \mathrm{[19].}$ The requirement of salt concentration for precipitation is dependent on the properties and concentration of proteins present in the starting solution. However, the inulinase activity of $B$. aquimaris remained in the supernatant; this implied that the inulinase protein did not precipitate well as shown low specific activity in Table 1. On the other hand, the precipitated proteins contained some inulinase and some other proteins. This effect may cause from short time precipitation (only $1 \mathrm{~h}$ ), resulting in less efficiency of binding between salt and inulinase. The protein may have thick hydration shells, leading to difficult precipitation.

Alcohol precipitation used ethanol as the precipitant at concentrations from $20-50 \%$ (Figure 1(b)); the results showed that $50 \%$ ethanol precipitation gave the highest enzyme activity at $338 \mathrm{U}$, the specific activity of 26.21 $\mathrm{U} / \mathrm{mg}$. Other studies using ethanol precipitation in exoinulinase from $K$. marxianus YS-1 [4]; the specific activity of $47 \mathrm{IU} / \mathrm{mg}$ was achieved with $85 \%$ (v/v) chilled ethanol. [16] purified inulin fructotransferase (DFA III-forming) from $A$. aurescens SK 8.001 by pre-chilled $\left(-20^{\circ} \mathrm{C}\right) 60 \%$ (v/v) of ethanol at $4^{\circ} \mathrm{C}$ for $1 \mathrm{~h}$, giving specific activity at $18.7 \mathrm{U} / \mathrm{mg}$. The fructosyltransferase from Rhodotorula sp. was purified using ethanol precipitation up to $70 \%$ at $4^{\circ} \mathrm{C}$, showing the specific activity of $0.2 \mathrm{U} / \mathrm{mg}$ (fructofuranosidase) and $0.5 \mathrm{U} / \mathrm{mg}$ (fructosyl-transferase) [25]. The ethanol has an effect of dielectric constant on the ability of water solubility depending on kind of proteins. The ethanol concentration is low; the fully enzyme precipitation might not occur. With high ethanol concentration, it can denature proteins, also may reduce enzyme activity and purification factor as containing some inhibitors [26]. 
a) Ammonium sulfate precipitation

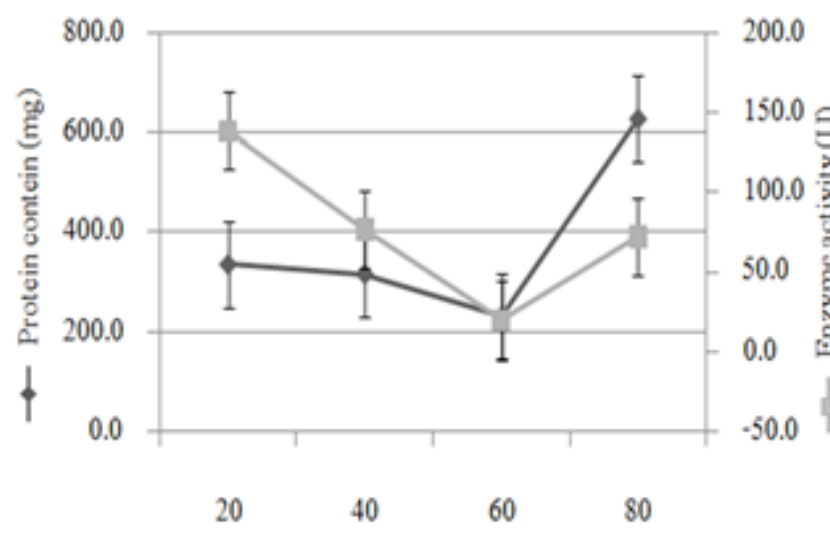

Ammonium sulfate concentrations

c) Butanol precipitation

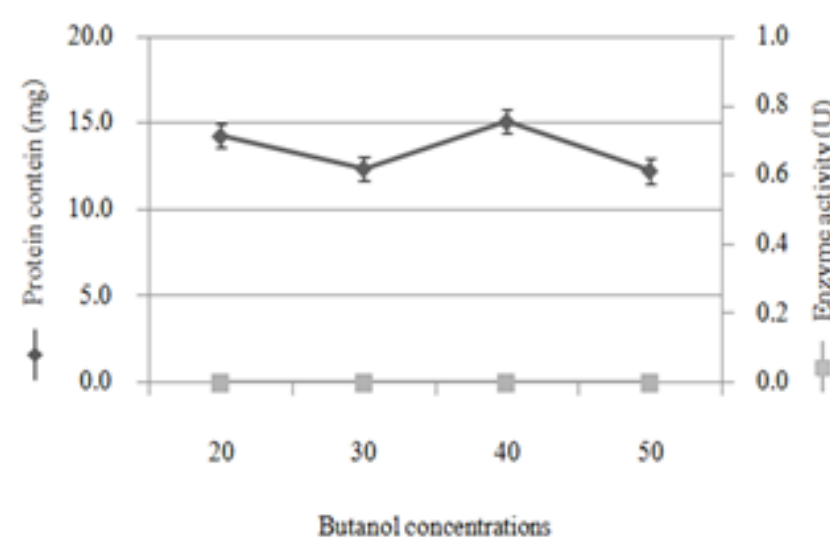

b) Ethanol precipitation

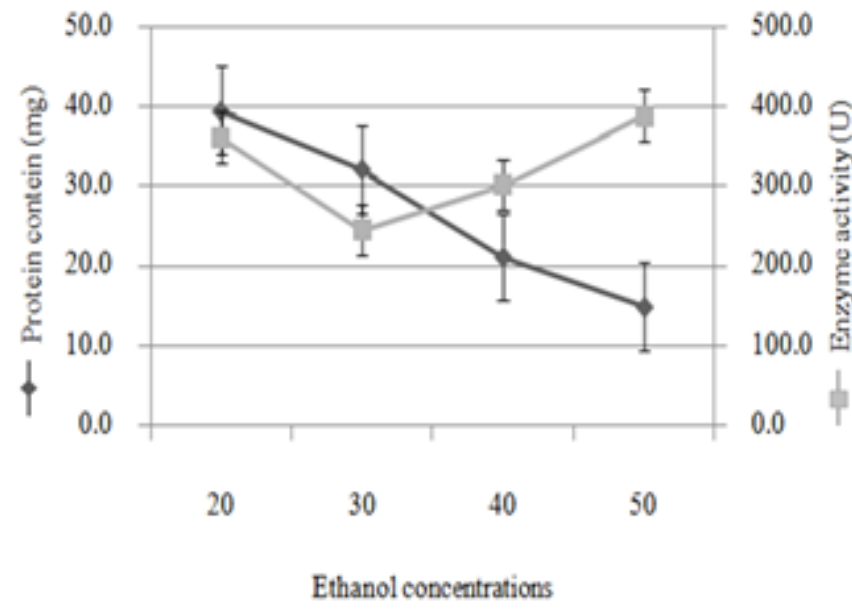

d) 2-steps of salt and alcohol precipitation

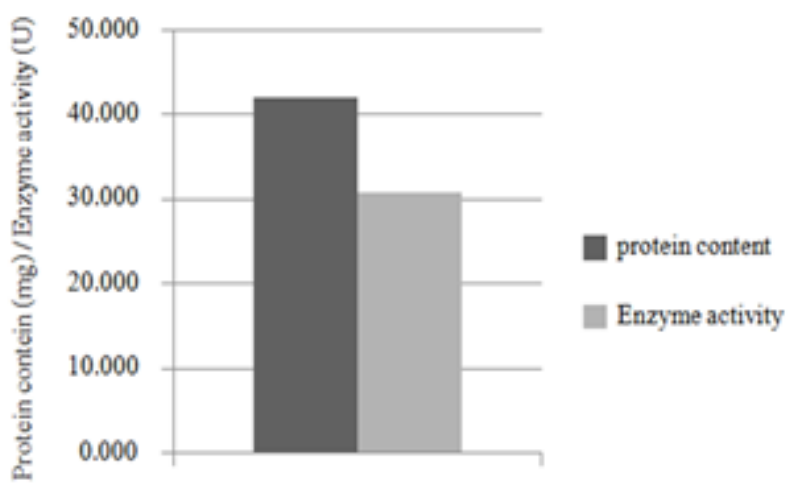

Fig. 1. Enzyme activity and protein content of inulinase in different precipitation methods.

In terms of butanol precipitation using t-butanol as the precipitant at concentrations from $20-50 \%$, the results showed $40 \%$ of butanol giving the highest protein content (15 mg), but enzyme activity was not found (Figure 1(c)). The protein content and inulinase activity remained in the supernatant. This indicated that t-butanol required salts for protein precipitation. 2-steps of salt and alcohol (ammonium sulfate and t-butanol) showed enzyme activity at $31 \mathrm{U}$ with $42 \mathrm{mg}$ protein (Figure 1(d)). However, the protein contents of alcohol precipitation were very low and not enough for purification. This effect may cause by unfavorable interaction between polar groups of the protein and ethanol, leading to protein solubility. In contrast, the non-polar groups have favorable interactions with ethanol decrease protein solubility, causing protein precipitation [13]. The alcohols could inhibit protein functions by changing the conformation of protein which affected from loss of stability in hydrophobic interaction. Moreover, the long chain of hydrocarbons or high con- centration of alcohol and high temperature are the major effects to damage protein structure [13].

Table 1 shows the crude enzyme of $B$. aquimaris with inulinase activity at $729 \mathrm{U}$ and the protein content was $452 \mathrm{mg}$ by Lowry's method, resulting in specific activity at $1.16 \mathrm{U} / \mathrm{mg}$. The optimum condition of each precipitation method also shown in Table 1 to compare the suitable method for inulinase purification. The precipitation with $50 \%$ ethanol gave small amounts of protein content, but the specific activity, percentage of recovery and purification were the highest values. This implied that all protein contents that precipitated were inulinase. The effect of ethanol is not consistent for all proteins, and its effects are varied depending on temperature. Thus, the condition of ethanol precipitation should be developed to decrease the effects of ethanol on protein structure or functions, e.g., using pre-chilled ethanol, performing at low temperature $\left(4^{\circ} \mathrm{C}\right)$. 
TABLE 1

COMPARISON OF VARIOUS METHODS FOR INULINASE CONCENTRATION IN BACILLUS AQUIMARIS

\begin{tabular}{llllll} 
Precipitation & $\begin{array}{l}\text { Total activity } \\
(\mathrm{U})\end{array}$ & $\begin{array}{l}\text { Total } \\
(\mathrm{mg})\end{array}$ & $\begin{array}{l}\text { Specific activity } \\
(\mathrm{U} / \mathrm{mg})\end{array}$ & Recovery (\%) & $\begin{array}{l}\text { Purification } \\
\text { (fold) }\end{array}$ \\
\hline & & & & & \\
Crude enzyme & 729 & 452 & 1.61 & 100 & 1 \\
20\% Ammonium sulfate & 138 & 335 & 0.41 & 18.98 & 0.26 \\
50\% Ethanol & 388 & 15 & 26.21 & 53.25 & 16.24 \\
Butanol & 0 & 0 & 0 & 0 & 0 \\
2-steps of salt and alcohol & 31 & 42 & 0.73 & 4.21 & 0.45 \\
\hline
\end{tabular}

\section{CONCLUSION}

In this study, different precipitation methods of inulinase were investigated, including ammonium sulfate, ethanol, t-butanol, and 2-steps of salt and alcohol. The optimum condition of ammonium sulfate was $20 \%$ showing $19 \%$ recovery; however, this method seems to be not specific to inulinase as shown low specific activity. The suitable method of inulinase from B. aquimaris was $50 \%$ of ethanol precipitation showing high protein recovery and high purification. This method was specific to inulinase but it needs to study the optimum condition of procedure to achieve high protein contents. The modified method of ethanol precipitation may be used as a simple purification technique for inulinase from the endophytic bacteria, which may be applied in fructose-syrup production from inulin of Jerusalem artichoke.

\section{REFERENCES}

[1] E. J. Vandamme and D. G. Derycke, "Microbial inulinases: Fermentation process, properties, and applications," Advances in Applied Microbiology, vol. 29, pp. 139-176, 1983. doi: https://doi.org/10. 1016/s0065-2164(08)70356-3

[2] N. Kaur and A. K. Gupta, "Applications of inulin and oligofructose in health and nutrition," Journal of Biosciences, vol. 27, no. 7, pp. 703-714, 2002. doi: https://doi.org/10.1007/bf02708379

[3] W. Liebl, D. Brem, and A. Gotschlich, "Analysis of the gene for $\beta$-fructosidase (invertase, inulinase) of the hyperthermophilic bacterium Thermotoga maritima, and characterisation of the enzyme expressed in Escherichia coli," Applied Microbiology and Biotechnology, vol. 50, no. 1, pp. 55-64, 1998. doi: https://doi.org/10.1007/s002530051256

[4] R. S. Singh, R. Dhaliwal, and M. Puri, "Partial purification and characterization of exoinulinase from Kluyveromyces marxianus YS-1 for preparation of high-fructose syrup," Journal of Microbiology and Biotechnology, vol. 17, no. 5, pp. 733-738, 2007.
[5] P. Bunruk, D. Kantachote, and A. Sukhoom, "Isolation and selection of purple non-sulfur bacteria for phosphate removal in rearing water from shrimp cultivation," Journal of Applied and Physical Sciences, vol. 3, no. 2, pp. 73-80, 2017. doi: https://doi.org/10.20474/japs-3.2.5

[6] S. Sirisansaneeyakul, S. Jitbanjongkit, N. Prasomsart, P. Luangpituksa et al., "Production of $\beta$-fructofuranosidase from Aspergillus niger ATCC20611," Kasetsart Journal Natural Science, vol. 34, pp. 378-386, 2000.

[7] A. Fuchs, "Production and utilization of inulin. Part II: Utilization of inulin," in Science and Tecnology of Fructans, M. Suzuki and N. J. Chatterton, Eds. Boca Raton, FL: CRC Press, 1993, pp. 319-352.

[8] D. Dorrell and B. Chubey, "Irrigation, fertilizer, harvest dates and storage effects on the reducing sugar and fructose concentrations of Jerusalem artichoke tubers," Canadian Journal of Plant Science, vol. 57, no. 2, pp. 591-596, 1977. doi: https: //doi.org/10.4141/cjps77-084

[9] B. Chubey and D. Dorrell, "Jerusalem artichoke, a potential fructose crop for the prairies," Canadian Institute of Food Science and Technology Journal, vol. 7, no. 2, pp. 98-100, 1974. doi: https: //doi.org/10.1016/s0315-5463(74)73870-6

[10] Z. Chi, Z. Chi, T. Zhang, G. Liu, and L. Yue, "Inulinase-expressing microorganisms and applications of inulinases," Applied Microbiology and Biotechnology, vol. 82, no. 2, pp. 211-220, 2009. doi: https://doi.org/10.1007/s00253-008-1827-1

[11] R. Nagem, A. Rojas, A. Golubev, O. Korneeva, E. Eneyskaya, A. Kulminskaya, K. Neustroev, and I. Polikarpov, "Crystal structure of exo-inulinase from Aspergillus awamori: The enzyme fold and structural determinants of substrate recognition," Journal of Molecular Biology, vol. 344, no. 2, pp. 471-480, 2004. doi: https://doi.org/10.1016/j.jmb. 2004.09 .024 
[12] Y. Tsujimoto, A. Watanabe, K. Nakano, K. Watanabe, H. Matsui, K. Tsuji, T. Tsukihara, and Y. Suzuki, "Gene cloning, expression, and crystallization of a thermostable exo-inulinase from Geobacillus stearothermophilus KP1289," Applied Microbiology and Biotechnology, vol. 62, no. 2-3, pp. 180-185, 2003. doi: https://doi.org/10.1007/ s00253-003-1261-3

[13] H. Yoshikawa, A. Hirano, T. Arakawa, and K. Shiraki, "Mechanistic insights into protein precipitation by alcohol," International Journal of Biological Macromolecules, vol. 50, no. 3, pp. 865-871, 2012.

[14] C. Dennison and R. Lovrien, "Three phase partitioning: Concentration and purification of proteins," Protein Expression and Purification, vol. 11, no. 2, pp. 149-161, 1997. doi: https://doi.org/10.1006/ prep.1997.0779

[15] H. T. T. Hanh and W. Mongkolthanaruk, "Correlation of growth and IAA production of Lysinibacillus Fusiformis UD 270," Journal of Applied and Physical Sciences, vol. 3, no. 3, pp. 98-106, 2017. doi: https://doi.org/10.20474/japs-3.3.3

[16] M. Zhao, W. Mu, B. Jiang, L. Zhou, T. Zhang, Z. Lu, Z. Jin, and R. Yang, "Purification and characterization of inulin fructotransferase (DFA III-forming) from Arthrobacter aurescens SK 8.001," Bioresource Technology, vol. 102, no. 2, pp. 1757-1764, 2011. doi: https://doi.org/10.1016/j.biortech.2010. 08.093

[17] S. Meenakshi, S. Umayaparvathi, P. Manivasagan, M. Arumugam, and T. Balasubramanian, "Purification and characterization of inulinase from marine bacterium, Bacillus cereus MU-31," Indian Journal of Geo-Marine Sciences, vol. 42, no. 4, pp. 510-515, 2013.

[18] H. M. Hussein, N. H. Zaki, and N. Sahira, "Purification and characterization of exoinulinase from $\mathrm{Pseu}$ domonas putida isolated from agricultural waste materials," Diyala Journal for Pure Science, vol. 10, no. 3-part 1, pp. 71-89, 2014.

[19] K. Naidoo, A. Kumar, V. Sharma, K. Permaul, and S. Singh, "Purification and characterization of an endoinulinase from Xanthomonas campestris pv. phaseoli KM 24 mutant," Food Technology and Biotechnology, vol. 53, no. 2, pp. 146-153, 2015.

[20] V. Vinoth Kumar, M. P. Premkumar, V. k. Sathyaselvabala, S. Dineshkirupha, J. Nandagopal, and S. Sivanesan, "Aspergillus niger exo-inulinase purification by three phase partitioning," Engineering in Life Sciences, vol. 11, no. 6, pp. 607-614, 2011. doi: https://doi.org/10.1002/elsc.201000180

[21] G. L. Miller, "Use of dinitrosalicylic acid reagent for determination of reducing sugar," Analytical Chemistry, vol. 31, no. 3, pp. 426-428, 1959. doi: https://doi.org/10.1021/ac60147a030

[22] O. H. Lowry, N. J. Rosebrough, A. L. Farr, and R. J. Randall, "Protein measurement with the Folin phenol reagent," Journal of Biological Chemistry, vol. 193, no. 1, pp. 265-275, 1951.

[23] S. A. I. Bokhari, F. Latif, and M. I. Rajoka, "Purification and characterization of xylanases from Thermomyces lanuginosus and its mutant derivative possessing novel kinetic and thermodynamic properties," World Journal of Microbiology and Biotechnology, vol. 25, no. 3, pp. 493-502, 2009. doi: https://doi.org/10.1007/s11274-008-9915-z

[24] A. Jabbar, M. H. Rashid, M. R. Javed, R. Perveen, and M. A. Malana, "Kinetics and thermodynamics of a novel endoglucanase (CMCase) from Gymnoascella citrina produced under solid-state condition," Journal of Industrial Microbiology \& Biotechnology, vol. 35, no. 6, pp. 515-524, 2008. doi: https://doi.org/10.1007/s10295-008-0310-4

[25] S. Hernalsteens and F. Maugeri, "Purification and characterisation of a fructosyltransferase from Rhodotorula sp." Applied Microbiology and Biotechnology, vol. 79, no. 4, p. 589, 2008. doi: https://doi.org/10.1007/s00253-008-1470-x

[26] S. Golunski, V. Astolfi, N. Carniel, D. de Oliveira, M. Di Luccio, M. A. Mazutti, and H. Treichel, "Ethanol precipitation and ultrafiltration of inulinases from Kluyveromyces marxianus," Separation and Purification Technology, vol. 78, no. 3, pp. 261-265, 2011. doi: https://doi.org/10.1016/j. seppur.2011.02.019 